\title{
Pelatihan Penanganan Bullying Pada Anak TK
}

\author{
Oleh: \\ Muthmainnah, Budi Astuti, Arumi Savitri Fatimaningrum \\ diwan_nafil@yahoo.co.id; budi_astuti@uny.ac.id; arumi.fatimaningrum@yahoo.com \\ FIP Universitas Negeri Yogyakarta
}

\begin{abstract}
Abstrak
Program ini bertujuan untuk meningkatkan pengetahuan guru TK dalam menangani bullying di TK. Khalayak sasaran dalam program ini adalah guru TK di wilayah Imogiri Bantul yang berjumlah 31 orang. Kegiatan ini dilaksanakan dengan metode ceramah, tanya jawab, pemberian tugas dan diskusi, danpresentasi. Pelatihan penanganan bullying pada anak TK dapat meningkatkan pengetahuan dan wawasan tentang pengertian bullying, jenis dan dan dampaknya bagi anak,serta penanganan yang tepat bagi pelaku, korban atau teman yang melihat tindak bullying serta orang tua. Hal ini dapat dilihat dari hasil evaluasi pelaksanaan kegiatan dan evaluasi penanganan masalah bullyingyang telah mencapai indikator keberhasilan melebihi $80 \%$. Berdasarkan hasil penyebaran skala tentang penyelenggaraan kegiatan dapat disimpulkan bahwa $100 \%$ guru TK (31 peserta) merasa materi disampaikan dengan jelas dan sesuai serta bermanfaat bagi peserta. Berdasarkan rubrik penilaian dalam diskusi penanganan bullying, 5(lima) kelompok mencapai kriteria baik dalam merancang penanganan bullying, baik untuk pelaku bullying, korban bullying, teman yang melihat bullying maupun penanganan untuk orang tua.
\end{abstract}

Kata Kunci: penanganan, bullying, anak TK

\begin{abstract}
This service program is aim at improving the teacher's knowledge in handling bullying in Kindergarten. The participants of this program is 31 Kindergarten teacher's in Imogiri Bantul. The activity is carried out using methods of lecturing, questions and answer, giving assigment and discussion, and presentation. The training of handling bullying among Kindergarten children can improve the knowledge and insight about the definition, the kinds, and the impact of bullying to the children, and also the ways of handling the actors, victims or other children who see the bullying action and their parents. This can be seen from the evaluation of handling the problems of bullying which has reached the achivements indicator of more than $80 \%$. Based on the scale survey about the program it can be concluded that $100 \%$ of the Kindergarten teachers think that the program materials are delivered clearly, suitable, and beenefit for them. Based on the evaluation rubrics in discussion of handling bullying, five groups has reached the good grade in designing the way to handle bullying, either for the actors, of bullying, the victims of bullying, other children who see the bullying, or the way handle their parents.
\end{abstract}

Key words: handling, bullying, kindergarten children

\section{Pendahuluan}

Berbagai pengalaman sosial yang
dialami anak dapat membantu mengembangkan kemampuan sosial, memperkuat mental dan ketahanan anak ketika menghadapi suatu masalah. Dalam 
rangka membantu anak mempersiapkan diri menghadapi tantangan sosial, maka orang dewasa (orang tua, pendidik, pengasuh) perlu membekali anak dengan keterampilan sosial agak anak mampu menyikapi permasalahan sosialnya dengan baik dan pengalaman sosial yang dialami tidak menimbulkan ketakutan atau trauma bagi anak. Salah satu tantangan sosial anak yang seringkali dihadapi anak adalah kekerasan. Pada dasarnya, setiap anak berhak untuk merasakan keamanan, kedamaian dan kebahagiaan. Namun, tak jarang anak-anak mengalami berbagai bentuk kekerasan.

Wikipedia Indonesia (2006) memberikan pengertian bahwa kekerasan mengarah pada tindakan agresi dan pelanggaran (penyiksaan, pemerkosaan, pemukulan, dan sebagainya) yang menyebabkan atau dimaksudkan untuk menyebabkan penderitaan atau menyakiti orang lain. Pada umumnya kekerasan cenderung dimaknai sebagai tindakan agresif untuk melakukan perilaku yang merusak (destruktif). Kekerasan yang dialami anak sangatlah bervariasi, mulai dari kekerasan verbal, mental sampai fisik, mulai dari kekerasan ringan sampai berat yang dapat menimbulkan dampak traumatik. Pelaku kekerasan umumnya justru dilakukan oleh orang-orang yang seharusnya bertanggung jawab dan dapat dipercaya oleh anak seperti orang tua, keluarga dekat, dan guru.

Berdasarkan hasil wawancara dengan tiga guru di TK daerah kecamatan Jetis Bantul, ditemukan fakta adanya tindakan bullying. Bentuk bullying yang muncul bervariasi, namun lebih banyak didominasi dengan bentuk verbal seperti memanggil dengan julukan yang tidak baik, mengejek, mengolok-olok, nyuraki dan bentuk verbal lainnya.Selanjutnya disusul dengan bentuk fisik seperti memukul teman, menendang dan mencubit. Sementara bentuk gesture seperti memandang dengan sinis paling jarang dilakukan anak. Hasil observasi mengungkapkan bahwa sebagian guru menganggap bullying dalam bentuk verbal sebagai hal yang wajar atau biasa. Hasil wawancara dengan guru juga mengungkapkan fakta bahwa pelaku (bully) umumnya anak yang sama. Sebagai upaya untuk mengatasi, guru lebih cenderung mengamankan korban (victim), sementara pelaku hanya dinasehati saja atau bahkan dimarahi, yang kecenderungan dapat memunculkan perilaku bullying yang terulang. Idealnya penanganan bersifat seimbang, baik untuk pelaku maupun korban. Sebagian guru juga ada yang memberikan label troublemaker pada pelaku yang dapat berdampak negatif pada aspek psikologis anak.

Bullying sebenarnya berdampak tidak hanya pada pelaku dan korban, melainkan anak-anak lain yang menyaksikan dan mendengarkan bullying. Hal ini sesuai dengan pendapat Salmivalli et al. (1996) bahwa semua anak di suatu kelas atau sekolah tertentu terlibat dalam proses bullying, meskipun tidak secara aktif berpartisipasi dalam perilaku bullying. Respon anak-anak terhadap bullying dapat mempengaruhi terulangnya bullying tidak. Berdasarkan hasil observasi, penanganan bullying umumnya terbatas pada pelaku dan korban, sedangkan anak-anak lain tidak menjadi sasaran penanganan bullying. Pendekatan dengan keluarga juga belum dilakukan, baik dengan keluarga pelaku maupun korban. Oleh karena itu, guru perlu memiliki pengetahuan dan penanganan yang tepat pada perilaku bullying, agar dapat mengatasi perilaku bullying di kelas,meminimalisir dampak negatif pada pelaku, korban maupun teman-teman yang lain di kelas dan tentunya pelaku dapat menghentikan kebiasaan bully nya.

\section{Identifikasi Masalah}

1. Sebagian guru menganggap bentuk bullying verbal sebagai hal biasa.

2. Penanganan lebih ditekankan pada korban, sedangkan pelaku cenderung hanya dinasehati atau bahkan dimarahi. 
3. Anak-anak lain yang bukan korban belum menjadi sasaran penanganan bullying, sehingga memungkinkan perilaku bullying terulang.

4. Belum adanya pendekatan dengan keluarga dalam penanganan bullying.

\section{Perumusan Masalah}

Bagaimana

meningkatkan

pengetahuan guru TK dalam menangani bullying di TK?.

\section{Tujuan Kegiatan}

Adapun tujuan yang akan dicapai dalam PPM ini adalah:

1. Meningkatkan pengetahuan guru-guru TK tentang penanganan bullying di TK.

2. Mendorong guru-guru TK agar melakukan penanganan yang tepat terhadap bullying di TK, baik dengan pendekatan pada anak maupun pada orang tua.

\section{Pengertian Kekerasan Pada Anak}

Secara umum, kekerasan mengandung makna perilaku agresif yang merusak. Sutanto (2006) mengungkapkan bahwa kekerasan anak adalah perlakuan orang dewasa atau anak yang lebih tua dengan menggunakan kekuasaan/ otoritasnya terhadap anak yang tak berdaya yang seharusnya menjadi tanggung jawab/ pengasuhnya, yang berakibat penderitaan, kesengsaraan, cacat atau kematian. Wikipedia Indonesia (2006) memberikan pengertian bahwa kekerasan merujuk pada tindakan agresi dan pelanggaran (penyiksaan, pemerkosaan, pemukulan, dan sebagainya.) yang menyebabkan atau dimaksudkan untuk menyebabkan penderitaan atau menyakiti orang lain. Ancaman merupakan salah satu bentuk kekerasan yang bisa mengakibatkan luka, baik luka fisik, perasaan, maupun pikiran, yang dapat merugikan kesehatan dan mental seseorang. Pelaku kekerasan terhadap anak umumnya adalah mereka yang seharusnya justru bertanggung jawab pada anak, yang seharusnya dapat dipercaya, misalnya orang tua, keluarga dekat, dan guru.

Kekerasan pada anak bukanlah hal baru dan sudah merupakan masalah yang serius. Hal ini diperkuat dengan studi yang dilakukan Yayasan Kesejahteraan Anak Indonesia (YKAI) menemukan bahwa secara kuantitatif ada kecenderungan terjadinya peningkatan tindak kekerasan terhadap anak. Pada tahun 1994 tercacat 172 kasus, pada tahun 1995 tercatat 421 kasus, pada tahun 1996 melonjak menajdi 476 kasus. Catatan ini adalah contoh kekerasan yang diekspos oleh media, barangkali bentuk kekerasan yang tidak diekspos masih banyak terjadi di masyarakat (Bagong Suyanto, 2010: 23). Dengan melihat adanya tindak kekerasan pada anak yang semakin meningkat, maka perlu adanya tindakan tegas yang solutif agar anak memperoleh haknya untuk hidup nyaman, damai dan bahagia. Sampai saat ini masih banyak terjadi bullying di sekolah yang penanganannya belum tuntas. Beberapa korban enggan untuk melapor dan lebih memilih untuk diam.

\section{Faktor Penyebab Kekerasan Pada Anak}

Menurut hasil pengaduan yang diterima Komnas Perlindungan Anak (2006), pemicu kekerasan terhadap anak diantaranya yaitu:

a. Kekerasan dalam rumah tangga, yaitu keluarga yang mengalami tindak kekerasan, baik melibatkan pihak ayah, atau ibu atau saudara yang lain. Kondisi ini dapat memicu munculnya kekerasan pada anak. Anak seringkali menjadi sasaran kemarahan orang tua. Menurut Anita Lie, ibu tega menganiaya anakanaknya sebagai salah satu bentuk pelampiasan ketidakberdayaan seorang isteri kepada suaminya.

b. Disfungsi keluarga, yaitu peran orang tua yang tidak berjalan sebagaimana mestinya. Beberapa kasus bisa diamati ketika seorang ayah di PHK atau kehilangan pekerjaan. Kondisi ini membuat ayah stres dan melampiaskannya pada anak dan 
keluarga. Peran ibu sebagai sosok yang menyayangi menjadi terkikis karena ibu terlalu lelah membanting tulang untuk memenuhi kebutuhan keluarga, sehingga tak lagi mampu menunjukkan kasih sayangnya. Bahkan kelelahan fisik dan psikis menyebabkan munculnya rasa dan sikap sensitif seperti cepat tersinggung, cepat marah dan sebagainya.

c. Faktor ekonomi, yaitu kekerasan timbul karena tekanan ekonomi. Kehidupan ekonomi yang mengalami tekanan mendorong munculnya kelelahan dan stres. Kondisi dapat memicu munculnya kekerasan.

d. Pandangan keliru tentang posisi anak dalam keluarga. Artinya, orang tua menganggap bahwa anak tidak tahu apa-apa, sehingga orang tua berhak memberikan perlakuan dan gaya penagsuhan apapun. Selain itu, tayangan-tayangan televisi atau mediamedia lainnya juga dapat menjadi faktor pemicu.

\section{Jenis-Jenis Kekerasan (Abuse)}

Seorang psikiater internasional yaitu Terry E. Lawson membagi bentuk kekerasan terhadap anak menjadi empat jenis, yaitu emotional abuse, verbal abuse, physical abuse, dan sexual abuse.

a. Kekerasan psikis atau emosi (emotional abuse), terjadi ketika orang dewasa (orang tua, pendidik, pengasuh dan pihak lain) tidak memberikan perhatian dan mengabaikan anak. Misalnya orang tua yang membiarkan anaknya kelaparan karena orang tua terlalu sibuk atau sedang tidak ingin diganggu. Selain itu, mempermalukan anak di depan umum dan seringkali menyalahkan juga termasuk emotional abuse. Apabila hal ini dilakukan secara terus menerus, dikhawatirkan dapat menyebabkan trauma atau kecemasan pada anak.

b. Kekerasan verbal (verbal abuse), terjadi ketika orang dewasa (orang tua, pendidik, pengasuh dan pihak lain) menggunakan kekerasan dalam bentuk kata-kata atau verbal. Bentuk ri verbal abuse misalnya penggunaan kata-kata kasar dan ancaman yang berlebihan dengan kata-kata. Memanggil anak dengan nama yang tidak baik dan anak tersebut tidak menyukai panggilan tersebut juga termasuk verbal abuse. Yang dikhawatirkan yaitu apabila anak akan mengingat semua kekerasan verbal jika terjadi dalam satu periode waktu.

c. Kekerasan fisik (physical abuse), terjadi ketika orang dewasa (orang tua, pendidik, pengasuh dan piha lain) melukai fisik anak seperti memukul, menendang, menampar, mendorong anak, dan perilaku fisik kasar lainnya. Anak akan mengingat perlakuan fisik yang kasar jika kekerasan fisik itu berlangsung dalam periode tertentu, apalagi yang meninggalkan luka fisik. Korban physical abuse umumnya memiliki bukti fisik berupa luka memar, berdarah, patah tulang dan bentuk luka fisik lainnya.

d. Kekerasan seksual (sexual abuse), terjadi ketika orang dewasa (orang tua, pendidik, pengasuh dan pihak lain) melakukan tindakan yang mengarah pada pelecehan, pencabulan atau penyiksaan seksual. Sexual abuse dapat menyebabkan trauma pada korban, baik jangka pendek maupun panjang.

\section{Dampak Kekerasan Pada Anak}

Dampak-dampak yang ditimbulkan akibat kekerasan terhadap anak (child abuse), antara lain:

a. Dampak kekerasan psikis

Kekerasan psikis

tidak meninggalkan bukti yang membekas atau nyata, sehingga sukar diidentifikasi. Dampak dari kekerasan psikis yaitu membuat anak minder, merasa tidak berharga, kurang percaya diri, sulit membina hubungan, menarik diri dari pergaulan, dan lemah dalam membuat keputusan (decison making).

b. Dampak kekerasan fisik 
Anak yang mendapat perlakuan keras dari pihak lain dapat menjadi agresif dan dikhawatirkan akan meneruskan gaya pengasuhan yang tidak tepat kepada anakanaknya kelak. Orang tua agresif dapat melahirkan anak-anak yang agresif. Lawson menjelaskan bahwa gangguan mental yang dialami seseorang berkaitan dengan perlakuan buruk yang diterima ketika masih kecil. Kekerasan fisik yang berulang-ulang dan berlangsung dalam jangka waktu lama dapat menimbulkan dampak serius terhadap anak seperti korban meninggal dunia.

c. Dampak kekerasan seksual

Kekerasan seksual dapat meninggalkan luka yang mendalam bagi korban. Dampak kekerasan seksual yaitu adanya dendam terhadap pelaku, takut menikah, minder, dan trauma. Pengaruh yang ditimbulkan dari kekerasan seksual pada anak yang masih kecil seperti kecemasan, mudah mengompol, sulit tidur (insomnia), dan dampak lainnya.

d. Dampak penelantaran anak

Anak-anak yang mengalami kekerasan umumnya jauh dari perhatian dan kasih sayang. Hal ini diperkuat dengan pendapat Hurlock (1978) yang menyatakan apabila seorang anak kurang memperoleh kasih sayang dari orang tua, maka dapat menyebabkan tumbuhnya perasaan tidak aman, gagal mengembangkan perilaku, dan mengalami masalah penyesuaian diri pada masa yang akan datang.

\section{Dampak Perilaku Bullying}

$$
\text { Bullyingtentunya berdampak }
$$

negatif, baik pada pelaku, korban atau anak-anak lainnya yang menyaksikan dan mendengar perilaku bullying. Dampak tersebut diantaranya gangguan psikologis seperti trauma, dan kecemasan, penolakan teman sebaya, perilaku menyimpang, tidak nyaman di sekolah, dan sebagainya. Dampak lainnya yaitu dikhawatirkan anakanak lain yang mendengar atau menyaksikan akan memiliki persepsi bahwa bullyingdiperbolehkan. Hal ini dapat berdampak pada anak lain yang memungkinkan menjadi pelaku atau peniru karena takut menjadi sasaran berikutnya. Sebagian anak memilih diam saja tanpa melakukan apapun dan yang memprihatinkan yaitu apabila anak merasa tidak perlu menghentikannya.Berbagai penelitian juga menunjukkan hubungan antara bullyingdengan meningkatnya depresi, agresi dan penurunan prestasi belajar.

\section{Penanganan Bullying}

Bullying perlu ditangani dengan tepat, baik penanganan terhadap pelaku, korban, maupun teman-teman yang lain. Penanganan tersebut diupayakan baik oleh orang tua, guru dan masyarakat secara sinergi. Bentuk-bentuk penanganan yang umum terhadap pelaku bullying telah banyak dilakukan seperti pengembangan kebijakan anti bullying berbasis sekolah, resolusi konflik, dan konseling.

Orang tua dapat membantu anak melindungi dirinya dengan beberapa hal, diantaranya:

a. Orang tua menumbuhkan komunikasi yang hangat dengan anak

Komunikasi yang hangat dan terbuka dapat menumbuhkan rasa percaya anak pada orang tua. Orang tua sebaiknya dapat menajdi pendengar yang baik bagi anak-anaknya. Dominasi orang tua tampaknya bukan hal bijak dalam komunikasi. Artinya komunikasi yang hangat dibangun dua arah, sehingga anak pun memiliki kesempatan untuk mengungkapkan pikiran dan perasaannya. Apabila anak melakukan kesalahan, maka sebaiknya orang tua tidak semakin menyalahkan anak, atau bahkan memarahi. Sikap menyalahkan yang disertai dengan kemarahan orang tua dapat menimbulkan rasa takut pada anak, sehingga anak akan lebih memilih diam daripada menceritakan keadaan yang terjadi. Komunikasi yang hangat dan terbukadapatmembuatanak merasa nyaman. 
b. Memberikan pemahaman dan gambaran tentang kehidupan sosial, misalnya cerita

Orang dewasa (orang tua, pendidik, pengasuh) dapat menggunakan cerita dan dongeng untuk menggambarkan kehidupan sosial. Dalam cerita dapat dikisahkan bahwa anak akan menghadapi keadaan yang tidak menyenangkan, misalnya "ketika aku disakiti teman". Melalui cerita, anak tidak hanya dipersiapkan untuk mengetahui heterogenitas individu, ragam karakter, namun sekaligus diberikan pemahaman dan gambaran bagaimana menyikapi keadaan yang kurang menyenangkan. Anak juga diminta menceritakan pengalamannya dan dimintai pendapat.

c. Melakukan pengawasan ketika anak di rumah

Pengawasan merupakan salah satu tindakan preventif agar kekerasan pada anak dapat dicegah. Orang dewasa perlu mengetahui dengan siapa saja anak bermain. Anak juga perlu diberikan pemahaman untuk selalu pamit sebelum pergi, tidak bermain terlalu jauh, dan berhati-hati dengan orang asing.

d. Cermat terhadap perubahan anak, baik fisik maupun perilaku

Perubahan fisik seperti adanya darah, bekas luka atau yang lain memungkinkan adanya tindak kekerasan pada anak. Anak yang biasanya ceria, tapi tiba-tiba menarik diri dari lingkungan juga perlu dicermati oleh orang tua. Setelah orang tua mengamati perubahan, selanjutnya anak diajak berbincang untuk mengetahui lebih lanjut tentang kekerasan yang dialami anak.

e. Melatih anak untuk bersikap asertif

Asertif adalah menyatakan ketidaksetujuan atau penolakan dengan tegas. Orang tua dapat memberikan pesan pada anak untuk bersikap aserif apabila bertemu dengan orang asing, meskipun orang tersebut mengaku sebagai teman ayah atau ibu, atau mengiming-imingnya dengan makanan yang enak. Apabila anak disakiti temannya, maka anak dilatih untuk bersikap asertif, yaitu melawan dengan kata-kata, misalnya "badanku sakit kalau kau cubit". Orang tua dapat berpesan pada anak "lebih baik bertahan daripada menyerang". Membalas bukanlah ajang balas dendam, tapi bentuk bela diri agar tidak selalu disakiti (jadi sasaran/objek).

f. Bermain peran dengan anak untuk memberikan gambaran tentang cara menanggapi orang asing yang mendekati dirinya

Orang tua mengajak anak untuk bermain peran, misalnya ketika ada orang asing yang mengganggunya, ketika temannya menyakitinya (memukul, menendang, menggigit dan sebagainya), ketika ada orang yang melakukan pelecehan dan kekerasan lainnya.

g. Memberi dukungan emosional ketika anak mengalami ketakutan

Dukungan emosional sangat membantu untuk mengatasi rasa takutnya. Orang dewasa dapat menjadi pendengar yang baik, meyakinkan anak bahwa ia tidak sendirian dan semua akan baik-baik saja.

h. Meminta anak untuk mengingat alamat rumah atau salah satu nomor telepon dan melatihnya untuk menelpon

Anak perlu dilatih untuk menghafal alamat rumah, nama ayah dan ibu, alamat rumah, dan nomor telepon keluarga agar apabila suatu saat ada kejadian, maka anak tahu dimana dapat menghubungi keluarga.

i. Memberikan kesempatan anak untuk mengikuti kegiatan bela diri

Mengikutsertakan anak dalam beladiri juga dapat menjadi alternatif agar anak dapat menyikapi kekerasan yang dialaminya. Perlu diberikan pemahaaman bahwa bela diri bertujuan 
untuk melindungi diri, bukan untuk berkelahi.

j. Tidak menimbulkan kesenjangan sosial Terjadinya penculikan bisa jadi disebabkan karena adanya kesenjangan sosial. Gaya hidup yang terlihat "wah" dapat memancing perhatian orang untuk melakukan penculikan.

k. Melaporkan ke pihak sekolah untuk ditindak lanjuti

Apabila ada tindak kekerasan, maka diharapkan pihak korban dapat memberikan laporan dalam rangka penanganan lebih lanjut dan pencegahan terhadap munculnya kasus kekerasan lainnya.

Guru dan sekolah dapat membantu anak melindungi dirinya dengan beberapa hal, diantaranya:

a. Melek emosi

Anak dibiasakan untuk memiliki sikap empati dan saling menghargai perbedaan. Semakin banyak keanekaragaman yang ditemui anak, maka dapat membantu anak meningkatkan respect nya terhadap orang lain. Anak diberikan pemahaman bahwa perbedaan bukanlah suatu masalah, tapi suatu anugerah. Dengan perbedaan kehidupan bisa saling melengkapi. Guru membiasakan untuk memanggil teman dengan nama yang baik, menggunakan kata-kata yang sopan ketika berbicara, meminjam barang dengan baik, dan menegur dengan santun.

b. Melatih anak agar asertif

Asertif diperlukan agar anak mampu mengungkapkan pikiran dan perasaan dengan jujur tanpa menyinggung orang lain.

c. Melakukan pengawasan anak selama di sekolah

Guru memegang tanggung jawab ketika anak-anak berada di sekolah, sehingga guru perlu melakukan pengawasan terhadap perilaku anak. Apabila anak dijemput oleh orang lain tanpa konfirmasi, maka sebaiknya sekolah perlu waspada dan anak-anak diminta menunggu di dalam sekolah apabila belum dijemput orang tuanya, demi keamanan anak.

d. Memberikan penanganan yang tepat apabila terjadi bullying

Dalam penanganan bullying, pelaku dan korban perlu mendapatkan penanganan yang tepat. Bagi pelaku, diharapkan tidak mengulang perilaku negatifnya, sedangkan bagi korban, diharapkan dapat memaafkan pelaku dan kembali aktif dalam kehidupan sosial.

e. Memasukkan tema "melindungi diri" dalam pembelajaran

Teman "melindungi diri" dapat dijadikan alternatif tema pembelajaran di kelas. Anak diajak untuk memainkan permainan ular tangga dengan gambar emosi. Anak diminta bercerita tentang peristiwa yang menyenangkan dan menyedihkan sesuaia dengan yanag dialami. Dengan metode tersebut, guru tidak hanya mengetahui pengalaman setiap anak, namun guru juga dapat memberikan keterampilan agar anak dapat melawan kekerasan.

f. Pemberian sanksi yang tegas untuk pelaku kekerasan pada anak

Sebagian orang memiliki potensi menjadi pelaku kekerasan pada anak, termasuk guru. Saat ini belum banyak sekolah yang membuat kesepakatan tertulis tentang pelanggaran hak anak, kekerasan pada anak dan sanksi yang dikenakan pada pelaku. Dengan adanya aturan dan kesepakatan yang tegas, diharapkan dapat meminimalisir terjadinya kekeraasn pada anak. Pada awalnya, pelaku dapat diberikan peringatan, apabila masih mengulang maka dapat dikenakan skorsing.

g. Home visit

Kunjungan rumah diperlukan untuk lebih mengetahui keadaan anak di rumah sekaligus sebagaai kegiatan sharing dengan orang tua tentang gaya pengassuhan anak. Beberapa 
permasalahan yang muncul berkaitan dengan kekerasan adalah bahwa sumber kekerasan pada anak terjadi di rumah.

h. Parenting

Tidak semua orang tua mengetahui tentang gaya pengasuhan yang tepat, cara mengatasi masalah anak, dan kadangkala tidk menyadari dampak perilakunya terhadap perkembangan anak. Oleh karena itu, perlu adanya kegiatan parenting sebagai upaya memberikan pengetahuan dan keterampilan tentang kekerasan pada anak.

i. Memberikan terapi dan pendampingan bagi korban

Bagi anak yang menjadi korban kekerasan perlu diberikan terapi secara intensif untuk meminimalisir trauma yang terjadi. Selain itu pemdampingan yang berkelanjutan dapat membantu anak menyesuakan diri kembali dengan kehidupan sosial. Korban diberikan dukungan emosional agar tidak merasa sendiri dan terdiskriminasi.

\section{Khalayak Sasaran}

Khalayak sasaran yang dituju dalam pelatihan ini adalah guru TK di wilayah Imogiri Bantul yang berjumlah 31 orang.

\section{Metode Kegiatan}

Kegiatan dilaksanakan dengan metode ceramah, tanya jawab, pemberian tugas dan diskusi, danpresentasi. Metode ceramahdigunakan untuk memberikan pemahaman pada peserta tentang penanganan bullying di TK.

\section{Evaluasi Kegiatan}

Evaluasi yang digunakan dalam program ini yaitu evaluasi program dan evaluasi kemampuan guru. Untuk evaluasi penyelenggaraan digunakan angket yang diisi oleh peserta (format evaluasi terlampir). Indikator keberhasilan penyelenggaraan program ini yaitu apabila hasil angket memiliki signifikansi $80 \%$ artinya dari $80 \%$ peserta pelatihan menyatakan respon positif (materi jelas, sesuai dan bermanfaat) dalam penyelenggaraan program. Selain itu, indikator keberhasilan untuk evaluasi kemampuan guru dalam merancang solusi sebesar $80 \%$, artinya $80 \%$ peserta mampu merancang alternatif solusi untuk menangani bullying.

\section{Hasil Pelaksanaan Kegiatan}

Pelatihan penanganan bullying pada anak TK dilaksanakan dengan melibatkan guru-guru TK di wilayah Kecamatan Imogiri Bantul sebanyak 31 peserta. Kegiatan ini dilakukan dengan ceramah, tanya jawab, pemberian tugas, diskusi, dan presentasi.Berdasarkan hasil penyebaran angket tentang penyelenggaraan kegiatan dapat disimpulkan bahwa $100 \%$ guru TK (31 peserta) merasa materi disampaikan dengan jelas dan sesuai serta bermanfaat bagi peserta. Untuk panitia dan pelaksanaan kegiatan juga dirasa sudah baik. Hal ini dapat dilihat dari hasil pengisian angket yang rata-rata memperoleh skor 3 (kriteria baik) dan beberapa skor 4 (kriteria sangat baik). Adapun format evaluasi terlampir. Berdasarkan rubrik penilaian dalam diskusi penanganan bullying, masingmasing kelompok diminta menyampaikan salah satu contoh kejadian bullying di TK dan merancang penanganannya. Adapun permasalahan yang diangkat dalam diskusi kelompok yaitu 1) anak yang suka mencubit temannya; 2) anak yang suka mengejek dan mengancam teman; 3) anak yang suka mau menang sendiri dan memukul apabila tidak terpenuhi keinginannya; 4) anak yang menjadi korban bullying; dan 5) sikap orang tua yang kurang kooperatif dalam mengatasi permasalahan bullying (anaknya menajdi pelaku namun orang yua melindungi anak). Berdasarkan hasil diskusi kelompok yang kemudian dipresentasikan, 5 (lima) kelompok mencapai kriteria baik dalam 
rancangan penanganan bullying pada anak TK.

\section{Pembahasan}

Karakter anak dapat beralih dari egosentris menjadi sosiosentris. Berbagai pengalaman sosial yang dialami anak dapat membantu mengembangkan kemampuan sosial, sehingga egosentrismenya bisa diarahkan menjadi sosiosentris. Anak juga perlu belajar penyesuaian diri agar mampu bertahan ketika menghadapi suatu masalah. Dalam rangka membantu anak mempersiapkan diri menghadapi tantangan sosial, maka orang dewasa (orang tua, pendidik, pengasuh) perlu membekali anak dengan keterampilan sosial agak anak mampu menyikapi tantangan dan permasalahan sosialnya dengan baik, misalnya pertikaian dan pertengkaran dengan teman.

Salah satu tantangan sosial anak yang seringkali dihadapi anak adalah kekerasan. Kekerasan yang dialami anak sangatlah bervariasi, mulai dari kekerasan verbal, mental sampai fisik, mulai dari kekerasan ringan sampai berat yang dapat menimbulkan dampak traumatik. Kekerasan sebaiknya dapat diatasi sedini mungkin agar tidak berdampak negatif bagi perkembangan anak. Berdasarkan informasi dari kegiatan presentasi kelompok diperoleh data bahwa beberapa anak yang menjadi korban bullying menjadi enggan masuk sekolah karena merasa cemas dan tidak aman di kelas. Beberapa anak tersebut khawatir akan diganggu lagi oleh temannya. Selain itu, beberapa guru juga menyatakan umumnya anak yang menjadi korban bullying terkesan minder, tidak berdaya kalau diganggu dan kurang termotivasi dalam kegiatan diTK.

Intervensi terhadap kekerasan dapat dilakukan dengan mengidentifikasi sumber. Berdasarkan informasi melalui kegiatan tanya jawab dengan guru, ternyata sebagian besar bullying berasal dari rumah. seperti dari orang tua dan media televisi. Sebagian anak mencari perhatian di sekolah karena di rumah kurang perhatian, meniru (modelling) perilaku orang tua meskipun orang tua belum menyadari bahwa anak meniru perilaku negatifnya seperti mencubit, berkata kasar pada orang lain, mengancam dan perilaku negatif lainnya. Teman sebaya dapat juga memberikan pengaruh negatif pada anak apabila tidak mendapatkan pengawasan dan kontrol dari orang tua. Selain itu anak melihat acara televisi yang mengandung adegan kekerasan dan memparaktekkannya kepada teman-temannya.

Guru dan orang tua sebaiknya menyadari bahwa korban bullying memliki peluang menjadi pelaku di lain tempat dan di lain waktu, sehingga perlu ada penanganan agar masalah ini tidak berkelanjutan. Dalam hal ini guru perlu melakukan penanganan, baik kepada anak maupun orang tua melalui home visit dan parenting. Berdasarkan informasi melalui presentasi kelompok, sikap guru dalam penanganan bullying, tidak hanya berfokus pada korban, namun juga pada pelaku dan teman-teman yang melihat bullying. Untukpenanganan orang tua guru melakukan beberapa hal seperti dengan kunjungan rumah (home visit) untuk lebih mengetahui keadaan anak di rumah sekaligus sebagaai kegiatan sharing dengan orang tua tentang gaya pengasuhan anak. Parenting juga sebaiknya dilakukan sebagai kegiatan tindak lanjut bagi seluruh orang tua untuk memberikan informasi tentang gaya pengasuhan yang tepat bagi anak, dan cara mengatasi masalah bullying pada anak. Hal ini sesuai dengan pendapat Helen Cowie \& Dawn Jennifer (2009) tentang penanganan terhadap korban, anak lainnya dan orang tua.

Rancangan langkah-langkah penanganan guru meliputi: penanganan untuk pelaku, korban, teman dan orang tua. Penanganan untuk pelaku yaitu mengajak anak bicara mengenai apa yang dilakukan, menjelaskan bahwa tindakannya merugikan dirinya dan orang lain, membuat kesepakatan antara korban 
dan pelaku agar tidak mengulangi kejadian , mencari penyebab anak melakukan hal tersebut, berbicara dengan orangtua anak yang melakukan bully terhadap anak, serta home visit bila diperlukan. Penanganan untuk korban yaitu memberikan dukungan emosional ketika anak mengalami ketakutan, membekali anak dengan keterampilan asertif, meminta anak untuk berani melaporkan kepada guru atau orang tua, mendamaikan antara korban dan pelaku, serta meningkatkan rasa percaya diri anak dengan menonjolkan kelebihannya di kelas. Untuk teman-teman yang melihat bullying, guru mendorong anak untuk berani melaporkan ke guru atau menjadi mediator bagi temannya, tidak hanya sekedar menjadi penonton. Sedangkan untuk upaya untuk orang tua dilakukan melalui kegiatan home visit, parenting dan menjadi mediator bagi orang tua pelaku dan orang tua korban bullying.

\section{Penutup}

Pelatihan penanganan bullying pada anak TK dapat meningkatkan pengetahuan dan wawasan tentang pengertian bullying, jenis dan dan dampaknya bagi anak,serta penanganan yang tepat bagi pelaku, korban atau teman yang melihat tindak bullying serta orang tua. Hal ini dapat dilihat dari hasil evaluasi pelaksanaan kegiatan dan evaluasi penanganan masalah bullyingyang telah mencapai indikator keberhasilan melebihi $80 \%$. Berdasarkan hasil penyebaran angket tentang penyelenggaraan kegiatan dapat disimpulkan bahwa $100 \%$ guru TK (31 peserta) merasa materi disampaikan dengan jelas dan sesuai serta bermanfaat bagi peserta. Berdasarkan rubrik penilaian dalam diskusi penanganan bullying, 5(lima) kelompok mencapai kriteria baik dalam merancang penanganan bullying, baik untuk pelaku bullying, korban bullying, teman yang melihat bullying maupun penanganan untuk orang tua.

\section{Daftar Pustaka}

Bagong Suyanto. (2010). Masalah Sosial Anak. Jakarta: Prenada Media Group.

Dirjen PAUD Kementerian Pendidikan Nasional. Permendiknas No. 58 Tahun 2009.

Destriyana.

http://www.merdeka.com/gaya/kenal i-4-dampak-kekerasan-padaanak.html.

Firdaus. (2006). Faktor Penyebab Kekerasan Pada Anak.

Helen Cowie \& Dawn Jennifer. (2009). Penanganan Kekerasan Di Sekolah. Macanan Jaya Cemerlang.

Hurlock, E. (1998). Perkembangan Anak Jilid 1. Jakarta: Erlangga.

\section{Jawa Pos. Fakta tentang Kekerasan Pada} Anak.

Komnas Perlindungan Anak. (2006). Pemicu Kekerasan terhadap Anak

Mulyadi. (2003). Dampak Kekerasan Seksual. Diakses dari Sinar Harapan

Sutanto. (2006). Kekerasan Pada Anak.

Sirait. (2006). Dampak Kekerasan Pada Anak.

Tempo. (2006). Faktor Penyebab dan Dampak Kekerasan Pada Anak.

Terry E Lawson. Bentuk-bentuk kekerasan pada anak (child abuse). http://www.duniapsikologi.com/eker asan-pada-anak. Diakses tanggal 10 Maret 2015. 
http://www.kpai.go. Data Pelanggaran Hak

Anak. Diakses tanggal 12 Mei 2015.

http://www.duniapsikologi.com/dampakkekerasan-terhadap-anak/Diakses tanggal 12 Mei 2015.

Windoro

AT.

http://health.kompas.com/read.)

diakses tanggal 12 Mei 2015

Wikipedia. (2006). Pengertian kekerasan.

diakses tanggal 12 Mei 2015 